\title{
The Integration of Islam and Science Concept of Mehdi Golshaani's Perspective and Its Relevance to Islamic Education in The 4.0 Era
}

\author{
Agung Ilham Prastowo ${ }^{1}$, Setyo Pambudi ${ }^{2}$ \\ UIN Sunan Kalijaga Yogyakarta, Yogyakarta ${ }^{1}$, UIN Sunan Kalijaga Yogyakarta, Yogyakarta ${ }^{2}$ \\ \{agungelham684@gmail.com¹,pambudis650@gmail.com²\}
}

\begin{abstract}
The dichotomy between religion and science is one of the causes of the decline of Muslims. Ignorance of the development of science and technology has made muslims lag behind western countries and even colonized by them. The challenge of muslims is getting bigger with the emergence of the industrial revolution era 4.0 which demands the use of technological tools. The integration of religion and science is one solution to restore the glory of Muslims and catch up with Muslims from western countries. Islamic education has a central role in educating and developing muslims, so it is necessary to build an ideal integration model to achieve these goals. Mehdi Golshani is one of the figures who has initiated a model of integration of religion and science that needs to be studied more deeply. This research uses a qualitative approach with the research library method which digs up information data from various literary sources such as books, documents, pictures, mosaics, and others. The result of this research is that religion becomes the foundation and paradigm in developing science so that it is oriented for the benefit of humans. This integration provides great benefits for Islamic education, especially in the era of the industrial revolution 4.0 , which is to create an ideal, effective, efficient Islamic education model and produce competitive outcomes.
\end{abstract}

Keywords: Islam and science; Mehdi golshani; Era 4.0

\section{Introduction}

The issue of the integration of science and religion is still a hot debate in recent decades, this has emerged as a response to the separation between science and religion by the majority of western scientists. With this concept of integration,Muslims want to reverse the glory of Islam in the past, where science was in harmony with religion.In the golden age of the Islamic empire, Islam developed very rapidly due to the emergence of knowledge and technology. However, nowadays Islam's attention to science and technology has been greatly reduced, this can be seen from the backwardness of Muslims or Islamic countries from technological developments which is likely dominated by the West. Theefforts to integrate religion and science in Islamic countries experience various obstacles, such as a lack of attention to the development of science, weak public awareness of the importance of science, the assumption 
that science does not provide benefits in the hereafter. This has a negative effect if Muslims do not try to synergize with the development of science [1].

The conflicting or independent relationships between religion and science do not lead to comfortable social situations in the increasingly complex context of life. There are many potential problems and risks if the relationship between religion and science is viewed as one of the conflicts. Ideally, the relationship that leads to dialogue and integration between the two is much better [2].

The impact of the dichotomy of religion and science makes the majority of Muslims only deepen their religious knowledge because they think that only religious knowledge that must be studied. This makes Muslims lag behind because people who have mastery of religious knowledge will not be able to understand or recognize the development of knowledge outside their special fields of expertise. Linearity in the sciences of religion seems to be at high risk in the wider scope of social life, especially in the space including social networks.

Religious knowledge that is not accompanied by social science tends to underestimate and minimize the position and dignity of individuals [3]. For example, Ilmu Kalam/Aqidah, when it is not accompanied by sociological and anthropological analysis, it tends to be disrespectful and intolerant of other beliefs, especially in a society consisting of people of different beliefs and religions. Likewise, experts in the fields of anthropology, sociology, and medicine who do not understand religion are likely to harm.

A person's piety is not only seen from diligently doing rituals or his relationship with God alone, but also must include how to behave well in a pluralistic society, mutual respect, tolerance for the beliefs of others, mutual care and other forms of social behavior that can improve community harmony. To achieve this goal, it is not enough to study religion dogmatically but also to integrate it with social and scientific sciences. It is in this context that there should be an academic discussion about how to develop relationships between religion, science, and culture to foster a deeper understanding of interrelated issues [4].

The dichotomy of knowledgealso has an impact on the education system in Indonesia because of the legacy of the colonial education system which did try to separate religious knowledge from other sciences. This was inherited by the colonialists so that the Indonesian people only focused on religion and did not think about their nation, so it can strengthen the existence of the colonizers. On the other hand, the Muslim figures had the opinion that studying general science including science is not necessary because the essence of human life is the hereafter, so it is only religious knowledge that must be studied.

Based on these reasons, many Islamic educational institutions were apathetic to the development of science and technology which makes these educational institutions far behind. Efforts to develop science and technology in educational institutions have been carried out but there are still many shortcomings. Madrasah, Islamic boarding schools, and higher education have not been able to compete in terms of science and technology nationally or globally. Islamic education institutions must be able to integrate religious and scientific knowledge in a balanced manner so that they can produce qualified outcomes in the fields of religion and science.

On the other hand, general education institutions such as elementary school, junior high school, senior high school, vocational school do not seem to pay much attention to religious lessons so that they are used as formalities to meet the demands of state policies. Public education institutions emphasize more on intellectual abilities and skills without involving deep spiritual aspects. This can be seen from the allocation of an Islamic religious lesson schedule which is only two hours a week and does not seem serious in the learning process. Education in Indonesia, especially general education, is more oriented towards industrial 
interests without strengthening religion, morality and character. This phenomenon shows the polarization and dichotomy between religious knowledge and general science which will certainly have an impact on social life in society.

The efforts to integrate have been carried out by various muslim figures in the world, one of them is Mehdi Golshaani, a physicist who has a high concern for the progress of Muslims. The concept of integration of Mehdi Golshani is based on the word "Ilm" in the Qur'an, where the word "ilm" includes both religious and non-religious sciences, so it is necessary to integrate both in implementing it in everyday life. This concept has a major influence on the concept of science, especially in various Islamic educational institutions such as madrasas and Islamic schools.

Islamic education as a forum for developing Islamic scholarship has a big role in integrating science and Islam because Islam is not only studied at the level of dogma but also how Islam should be implemented in various aspects of life such as politics, economics, and society. So religion cannot stand alone and needs to be integrated with other scholarships [5] Entering the era of the Industrial Revolution 4.0, Islamic education is facing enormous challenges because it is required to keep pace with the very rapid developments in technology such as automation in various fields of work, humans must work together with machines to solve problems and various other innovations [6].

The emergence of this 4.0 era makes Islamic education not only stop in dogmatic teaching of Islam but how Islam can synergize with technology. In terms of the teaching and learning process, educators and students must be able to synergize with technology so that it has an effective, efficient, and quality impact. Educational institutions that are familiar with the use of technology will produce quality outcomes and are adaptive to technological development so that Islam becomes rahmatan lil 'alamin(mercy to the universe).Based on those problems, researchers are interested in further examining how the concept of integration of religion and science that was initiated by Mehdi Golshani and its relevance to Islamic education in the era of the industrial revolution 4.0.

\section{Method}

This research is included in the research library research category, which is a study using books as the data source. Library Researchis a way of working to find out scientific knowledge from a particular document or in the form of other literature put forward by previous scientists and scientists today [7].

This research library is used to solve research problems that are conceptual-theoretical. Sources of data in this study consisted of primary and secondary sources.[8] The primary data source in this study is "Integrasi Multidimensi Agama dan Sains" by Ach. Maimun Syamsudun, while the secondary data are books, journals, magazines, and others relating to the concept of integration according to Mehdi Golshani.

The data obtained, collected, arranged, and grouped into themes and sub-themes are then analyzed, interpreted proportionally,and critically reviewed with textual analysis and contextually applied according to research needs. This research method is used to obtain and build a concept of integration of religion and science of Mehdi Goslani and its relevance in the world of Islamic education in the era of 4.0. 


\section{Discussion and Result}

\subsection{Sources and Methods of Islamic Science on Mehdi Goslani's Perspective}

Mehdi Golssani was born in 1939 in Isfahan, Iraq. He studied in the city of Isfahan which was the center of science at that time, then continued his higher education at the University of Tehran in Physics and graduated in 1959. He continued his studies at the University of California, Berkeley USA in Physics faculty and graduated in 1969. He has written many books on science and technology, philosophy of science, Islamization of certain sciences, science in view of the Qur'an and others. Based on the education he took and the various books he wrote, it could be seen that he was a physicist figure who had more concern for Islam. He initiated the concept of the integration of religion and science through the analysis of scientific sources [9].

According to Golshani, the source of human knowledge are:

a. Sensesand intellect, In the physical world, the senses are the main source of knowledge, because the senses can relate directly to the real world [10]. It can be seen in the verses of the Al-Qur'an regarding the role of the senses in understanding nature, such as in Surah AlGhosiyah verse 88 concerning the creation of camels, sky, and mountains, Surat Al-A'rof verse 195 and Al-Anfal verse 21 concerning people who have hearts, eyes and ears. Another source of natural knowledge is reason or intellect. Al-Qur'an has shown the role of reason by the names Ulul Albab, ulul Abshar, tafaqquh, and others. To understand well about nature humans should use their senses and intellect, it is very difficult to understand nature only by senses. So, the intellect has a big role to understand natureand to interpret the physical realm and find wisdom and relationships between natural events. Intellect and senses will produce the basics in developing scientific methods and theories based on research and experiments to produce true natural laws.According to Golshani, Islamic science should not have created its scientific method that has Islamic characteristics or is different from other scientists. So, the scientific method has nothing to do with religion or can be said to be neutral because God has authorized humans to use reason to carry out experiments [11]. Golshani explained that observation and experimentation have their way that is different from religious beliefs in discovering science. So that there is no difference between Islamic and non-Islamic science in terms of methodology to find new things in science and Islam can collaborate with non-Islamic science. The difference between Islamic and non-Islamic science only lies in their orientation, namely the orientation of Islamic science is to make nature or scientific discoveries as evidence of Allah's power and to increase faith or belief in Allah [12].

b. Intuition, Intuitionis a direct source in reaching reality, which is religiously through the gift of God the giver of knowledge as an essential source. People who get knowledge directly from God are the elect, especially the prophets who were given revelation. The revelation given to the prophets is the highest intuition. A person who can cleanse the heart and an intense approach to Allah will acquire knowledge through intuition, just as the Sufis are those who gain knowledge of metaphysical realities through spiritual disclosure (Kasyf).According to Golshani the intuition of a scientist is different or lower than the intuition obtained by the prophets. Scientists' intuition is a mental talent honed through a serious learning process. To some extent, it resembles the reflex movement of people trained in action. Thus intuition in the world of science can penetrate the typographical realm as an object whose ontological existence is recognized in Islam [13]. 


\subsection{Integration of Religion and Science on Mehdi Ghozlani's Perspective}

Scientists continue to seek a constructive way on how to combine religion and science. They face various scientific problems that cannot be solved by science itself. This problem made scientists aware of the limitations of science so that on the other hand theologians reformulated the concepts of divinity. The concept of divinity is then used as a guide by scientists including Golshani in considering scientific findings [14].

Mehdi Golshani's idea of the integration of religion and science began with defining knowledge ('ilm) in Islam. There are fundamentally two opinions about knowledge, the first is that some figures argue that knowledge ('ilm) only shows the religious sciences or the science of sharia. Whereas the second, the opinion which says that ('ilm) does not only cover religious sciences but also includes all sciences both religion and science and technology and this is the opinion of the majority. Mehdi Golshani tends to agree with the second opinion, namely ('ilm) includes both religious and non-religious knowledge. He asserted that the good or the praise of knowledge in Islam depends on its benefit, for good or evil. So that any knowledge as long as it is for good and means of getting closer to Allah, then all efforts and ways to get that knowledge are a form of worship even though one is studied outside of religious knowledge [15].

Based on his epistemological study, Golshani concluded that the Al-Qur'an uses the word 'ilm or knowledge to discuss both natural sciences and religious sciences. Thus, he emphasized, the study of nature should be recommended to find God's patterns in the universe (kauniyah verses) and utilize them for the realization of the benefit of mankind. Islam views that everything in this universe moves around God so that God is the core, activator, and creator of everything that must be worshiped, including through science.

Mehdi Golshani rejects the modern scientific system which interprets science without involving Islam because Islam has functioned as a tool or medium for interpreting scientific data. Islam has an important role in interpreting scientific data, namely to avoid the negative impact of scientific materialism from values. Interpretation of scientific data through Islam will guide science to be used for human welfare, whereas if scientific data is interpreted through secular science it will ignore its usefulness for humans [16].

Golshani's concept of integration of religion and science is built on the paradigm of grouping science into two different categories, namely sacred sciences and secular sciences. Sacred science is a science that is built based onan atheistic world view, namely God as the center of the entire universe, God as creator and guardian. So that all forms of creatures and entities in this world are forms of the greatness of God because everything is centered on God. So studying, exploring, and studying this universe means trying to understand God's creation and increase faith in Him. Meanwhile, secular science has both worldly and material meanings and it is contrary to the concept of sacred science. This knowledge is built by putting aside its relationship with God in method, attitude, thought, and action. Secular science holds the view that science and religion are two different poles, so there is no need to integrate them [17].

The integration of religion and science will show the identity of science itself, namely religious values. Scientists who have religion will influence the orientation of science with religious values. For Golshani, the Islamic perspective is very important in constructing science. He created the concept of Islamic science as a real form of the integration of religion and science. He rejected the concept of value-free science so that it was impossible [18].

Gholsani emphasized that Islam must be an integral part of the development of science. $\mathrm{He}$ said that the Islamic worldview as the basis for science is built by religion. There are several components of the Islamic worldview that affect science and technology [19]. 
a. The impression of God, this concept influences the view that there is a unity of creator (God) and there is a relationship between His creations in the universe. This includes science, all knowledge is a gift from Allah to manage the earth. So that all scientific activities must be synthesized for harmony in life.

b. Belief in the supernatural and the limitations of human knowledge, this concept shows that the existence of this life does not only consist of the physical, but there is a reality that the human senses cannot grasp. Belief in reality and the limitations of the senses will lead to an understanding of the senses, non-sensory, and without certain limits.

c. Realizing the purpose of the creation of the universe, Allah declared that the creation of this universe was not for games, but would have a long-term goal, namely the afterlife. With the hereafter life or eternal life shows that all forms of creation have meaning.

d. hold fast to moral values. The development of science must be accompanied by knowledge of morals. If scienceis not followed by commendable morals, it will have a bad impact on life. So that the cultivation of morals and ethics is needed in the development of science to provide positive values in life.

Science and religion must be integrated in a balanced and constructive manner because they both have the same agreement in discovering the essence of existence and nature. Science and religion have a shared responsibility, so the problems of both must be solved accurately to solve life's problems. Problems faced such as disasters that occur in the present and future such as population poverty, climate change, erosion and drought, deforestation, waste, wealth inequality, crime, moral degradation, and other problems demand the right answers and solutions to manifest the role of science and religion as pro preservation of nature and humanity. This natural problem requires the role of religion and science to provide solutions so that a balanced and harmonious life can be created [20].

\subsection{Relevance Of Integration Of Religion And Science With Golshani With Islamic Education Era 4.0}

The European Parliamentary Research Service in Davies (2015) stated that the industrial revolution occurred four times. The development of the industrial revolution for the first time in 1784 in England which was marked by the discovery of the steam engine and mechanization began to replace human jobs. This phase is known as the first industrial revolution. Furthermore, at the end of the 19th century, there was a second industrial revolution, marked by the existence of production machines powered by electricity which were used to produce goods on a large scale. Furthermore, the 3rd industrial revolution occurred in 1970 which was marked by the development of sensor technology, interconnection, and data analysis which inspired the emergence of technology integration.Meanwhile, currently, it has entered the fourth industrial revolution marked by the digitization and automation of the combination of the internet and manufacturing, which has brought digitalization and automation of the combination of the internet with manufacturing. Industry 4.0 is announced a priori because the actual event has not yet occurred and is still in the form of ideas [21].

Industrial revolution 4.0 has a positive impact on human life, but on the other hand, it has a negative impact as expressed by Drath and Horch that the application of industry 4.0 will raise resistance to social order, unstable politics, weak resources and the risk of natural disasters. Revolution 4.0 also caused a high gap in the technological aspect between the industrial world and the conditions expected from 4.0. This makes some companies not use Industry 4.0 because of the uncertainty of its benefits [22]. 
The development of the Industrial Revolution 4.0 era has changed the order of people's lives, such as being able to communicate remotely across geographies, easy access to information from various media, the emergence of new jobs with various online-based applications and others. This change makes it easier for humans to meet their daily needs. But if the advancement of this technology is not balanced with high faith and religiosity, it will have a negative impact on society. For example, broadcasting negative content in videos, pictures, films, advertisements, and other entertainment products. So it is necessary to develop critical and religious or religious attitudes that can meet entertainment needs, aesthetic tastes and contain educational value to the community [23].

The era of the industrial revolution 4.0 requires an education pattern with an integrated curriculum (integrated curriculum) that is student-oriented capable of solving social problems and emphasizing the development of potential, talents, and student interests [24]. Islamic education must also open itself to the development of science while remaining based on Islam, especially in the era of the industrial revolution 4.0 so that it can innovate according to the demands of the times. Islamic education must reconstruct its curriculum, both in terms of content or materials and methods. Islamic education material must be more contextual, adaptive and accordance with the needs of the times, while in terms of learning methods, educators use technological tools to achieve efficiency and effectiveness [25].

The integration of religion and science in the 4.0 era can be done by moving Muslims to deepen the sciences and technology such as Medicine, Biology, Chemistry, Physics, Astronomy, Computing, Informatics, and others. Islamic education institutions, both Islamic higher education, and madrasah, must quickly respond to this need. Islamic higher education has responded to this scientific development by opening public faculties which are marked by the transfer of State Islamic religious institute (Institut Agama Islam Negeri) status to State Islamic University (Universitas Islam Negeri) [26].

Islamic schools or madrasas have also developed these sciences through government regulations, joint decrees; the Minister of Religion, the Minister of Home Affairs and the Minister of Education and Culture (SKB 3 menteri) have launched the concept of integration in Islamic schools or madrasas, namely by teaching $30 \%$ religious science and $70 \%$ general science.Based on these regulations, madrasas are obliged to develop their curricula by incorporating various general subjects such as science, social studies, economics, technology, and others. The development of science and technology has also been adopted by various Islamic boarding schools in Indonesia by establishing formal educational institutions such as junior high schools and senior high schools [27].

An integrative learning system must be further developed with various methods, for example, the teacher must be able to present integrative material, for example when the teacher teaches about prayer, not only talk about the arguments of the Qur'an and Hadith, the law, the procedures, terms, and conditions but also have to see the other side such as how it affects the social order of society so that it can be integrated with the social sciences. Prayer can also be studied in terms of physical and psychological health, so it needs to be integrated with natural science and psychology lessons.

Integrative learning can also be implemented outside the classroom through learning by doing system, project methods, and experiments, and others. Through these methods, students are not only required to be active in class but also required to be active in their environment. Students are given the task to carry out a project, for example helping parents according to their profession, for example helping parents to trade, so children are required to explore knowledge that includes Islamic religious lessons through trading procedures in accordance with Islamic laws, economic lessons through analysis of people's purchasing power, social 
and nationalism lesson through analysis of the interaction between sellers and buyers, treat all customers well regardless of ethnicity, race, and religion

In addition to developing integrative subject matter and methods, Islamic educational institutions such as Islamic universities, madrasah, and Islamic boarding schools must continue to develop science and technology more actively. The development of science and technology in several of these institutions has not been able to compete in the international world or has not been able to dominate world markets such as Apple, Alibaba, Google, and others. So Muslims must be more serious and work hard in terms of developing science and technology in this 4.0 era furthermore, the integration of Islam and science can be carried out by utilizing technological progress for the benefit of Islam. Utilization of the internet network as a means of preaching Islam or disseminating Islamic information, then technological tools for the benefit of Islamic teaching and learning facilities, determining the direction of the mosque's Qibla, determining the beginning of Ramadan and Syawal, predicting eclipses and others. Science and technology must be used for the benefit of humanity.

Based on this explanation, it can be concluded that the goodness or praise of both science and religion does not lie in the content or content, but lies in its use. Thus, discoveries in the field of science and technology can be used for the benefit of religion and humanity and as a means of proving the power of Allah and the breadth of God's knowledge.

\section{Conclusion}

Mehdi Goslani is very concerned about the integration of science and religion so that technological progress will bring benefits to humans. The integration of religion and science of Goslani is based on the word ('ilm) in the Qur'an, which means that it includes both religious and scientific knowledge so that every Muslim is obliged to study both. Science comes from reason or intellect and intuition in the form of revelation from Allah. Intellect is the source of knowledge through the universe, while revelation is the source of religion, so both of them come from Allah. There is no contradiction between the verses of Allah in the Qur'an and the universe which is Allah's creation.

Islamic education as a means of educating people must be sensitive to the integration of science and religion, especially entering the era of the industrial revolution 4.0 which is full of technology. This very fast technological development must be based on Islamic values. Islamic education must be able to take advantage of advances in science and technology for various Islamic purposes and for the convenience of teaching Islam. Islamic educational institutions must be better transformed by developing various scientific and technological sciences so that Islam can master them and provide great benefits to mankind in the world.

\section{References}

[1] Syukur, Abdus : Revitalisasi Teknologi Pendidikan Islam. Vol. 11, No. 2. pp. 48. Jurnal Tadris,(2016)

[2] Puspita, A. W., Siraturrahmah, R. M., \& Rijal, M. K.: Problematika dan Solusi Dikotomi Ilmu di Indonesia. Volume 5, No. 2, pp 2. Tarbiyah Wa Ta'lim: Jurnal Penelitian Pendidikan \& Pembelajaran (2018)

[3] Maksudin : Transformasi Pendidikan Agama dan Sains Dikotomik ke Pendidikan Nondikotomik. Volume IV, Nomor 2, pp. 282. jurnal Pendidikan Islam, (2015) 
[4] Abdullah, Amin: Religion, Science And Culture An Integrated, Interconnected Paradigm Of Science. Vol. 52, No. 1, pp. 180-181, Al-jami'ah Journal Islamic Studies (2014)

[5] Aripudin, Iis : Integrasi Sains dan Agama dan Implikasinya terhadap Pendidikan Islam. Volume 1, Nomor 1, pp. 171, jurnal Edukasia Islamika (2016)

[6] Priatmoko, Sigit : Memperkuat Eksistensi Pendidikan Islam di Era 4.0, Vol.1 No.2, pp. 223, Ta'lim Jurnal Studi Pendidikan Islam (2018)

[7] Hadi, Sutrisno : Metodologi Research. Jilid 1. Andi Offset, Yogyakarta, pp. 9 (1990).

[8] Singarimbun, Masri : Metode Penelitian Survey. LP3ES, Jakarta, pp. 45 (1989)

[9] Syamsudin, Ach. Maimun : Integrasi Multi Dimensi Agama dan Sains. Ircisod. Yogyakarta . pp. 123 (2012)

[10] Syamsudin, Ach. Maimun : Integrasi Multi Dimensi Agama dan Sains. Ircisod, Yogyakarta . pp. 261 (2012)

[11] Goshlani : The Holy Qur'an and the sciences of nature. Global Publications. New York, pp. 189 (1998)

[12] Syamsudin, Ach. Maimun : Integrasi Multi Dimensi Agama dan Sains. Ircisod, Yogyakarta . pp. 266 (2012)

[13] Syamsudin, Ach. Maimun : Integrasi Multi Dimensi Agama dan Sains. Ircisod, Yogyakarta . pp. 271 (2012)

[14] Ian G. Barbour: Juru Bicara Tuhan. Mizan, Bandung. pp. 13-14 (2002)

[15] Hidayatullah, Syarif : Relasi Agama dan Sains Dalam Pandangan Mehdi Golshani. Vol. 27, No. 1, pp. 76. Jurnal Filsafat (2017)

[16] Thoyib, Muhammad : Model Integrasi Sains dan Agama Dalam Perspektif J.F Haught Dan M.Golshani: Landasan Filosofis Bagi Penguatan PTAI di Indonesia. Volume 18, No, 01, pp. 16, Jurnal Akademika Iain Metro (2013)

[17] Musyoyih,. Salsabil, Aina : Kontribusi Konsep Sains Islam Mehdi Golshani Dalam Menyatukan Epistemologi Agama dan Sains. Volume 2, pp. 98 , Prosiding Integrasi Interkoneksi Islam dan Sains, UIN Sunan Kalijaga (2020

[18] Golshani, Mehdi : Issues In Islam And Science. Institute For Humanities And Cultural Studies (Ihcs). Tehran. Pp. 52. (2004)

[19] Golshani, Mehdi : "Sacred Science vs Islamic Science," dalam ed. Zainal Abidin Bagir, Science and Religion in a Post-colonial Wold, ATF Press, Australia, pp. 82-87 (2005)

[20] Hidayatullah, Syarif : Relasi Agama dan Sains Dalam Pandangan Mehdi Golshani. Vol. 27, No. 1, pp. 87. Jurnal Filsafat (2017)

[21] Prasetyo, Hoedi., Sutopo, Wahyudi : Industri 4.0, Telaah Klasifikasi Aspek dan Arah Perkembangan Riset. Vol. 13, No. 1, pp. 17-18. Undip: Jurnal Teknik Industri (2018)

[22] Qin, J., Liu, Y., \& Grosvenor, R. A : Categorical Framework of Manufacturing for Industry 4.0 and Beyond.. Vol. 52, pp. 173, Procedia CIRP, (2016)

[23] Syahri, Ahmad : Spirit Islam dalam teknologi pendidikan di era revolusi industri 4.0. Volume 28, pp. 72, Attarbiyah (2018)

[24] Nurcholiq, Mochamad : Desain Pengembangan Kurikulum Madrasah Aliyah Unggulan di Era Revolusi Industri 4.0. Vol. I No. 2 , pp. 221, Jurnal Piwulang (2019)

[25] Edison., Fathurrochman, Irwan : Pendidikan Sebagai Media Integrasi Agama dan Sains Dalam Era Revolusi Industri 4. Volume 3, No. 1. Pp. 186, Jurnal Literasiologi (2020)

[26] Yunus, Muh : Integrasi Agama dan Sains: Merespon Kelesuan Tradisi Ilmiah di PTAI. Vol. 19, No. 2, pp. 193, Jurnal Insania (2014)

[27] Irsad Muhammad : Pengembangan Kurikulum Pendidikan Agama Islam di Madrasah (Studi Atas Pemikiran Muhaimin). Vol. 2, No. 1, pp. 260, Iqra’ (2016) 